Studia i Materiały, 2/2016 (22), cz. 2: 185-193

\title{
Modelowanie panelowe cyklu życia filmu kinowego w Polsce
}

\begin{abstract}
Rafat Zbyrowski*, Natalia Gmerek ${ }^{* *}$
Celem autorów artykułu jest estymacja krzywej cyklu życia filmu kinowego w Polsce. Analiza została wykonana dla próby badawczej sktadajacej się z 175 polskich filmów fabularnych, które na przestrzeni ostatnich lat 2004-2014 obecne byty w kinach. Ksztatt krzywej cyklu życia filmu kinowego zostat wyznaczony przy użyciu danych panelowych (wptywów ze sprzedaży biletów kinowych przypadających na kopię). Dane dotyczace wptywów ze sprzedaży biletów kinowych zostaty pozyskane z serwisu branżowego boxoffice.pl.
\end{abstract}

Słowa kluczowe: modelowanie danych panelowych, cykl życia filmu kinowego, przychody ze sprzedaży biletów kinowych.

Nadesłany: 10.12.2016 | Zaakceptowany do druku: 29.12.2016

\section{Pooled Modelling of the Product Life Cycle of Feature Films in Poland}

The main purpose of this article is to estimate the average product life cycle of feature films produced in Poland.

The analysed sample consists of 175 motion pictures released between 2004 and 2014 for which complete data on the variables were available. The shape of movie life cycle curve was analysed using box office panel data (box office revenue per copy). The data concerning box office revenue were obtained from the boxoffice.pl website.

Keywords: panel/pooled data modelling, movie life cycle, box office revenue.

Submitted: 10.12.2016 | Accepted: 29.12.2016

JEL: M0, M2

" Rafał Zbyrowski - dr, Zakład Badań Operacyjnych, Wydział Zarządzania, Uniwersytet Warszawski. Adres do korespondencji: Zakład Badań Operacyjnych, Wydział Zarządzania, Uniwersytet Warszawski, ul. Szturmowa 1/3, 02-678 Warszawa; e-mail: rzbyrowski@wz.uw.edu.pl.

** Natalia Gmerek - dr, Katedra Marketingu, Wydział Zarządzania, Uniwersytet Warszawski. Adres do korespondencji: Katedra Marketingu, Wydział Zarządzania, Uniwersytet Warszawski, ul. Szturmowa 1/3, 02-678 Warszawa, e-mail: ngmerek@wz.uw.edu.pl. 


\section{Cykl życia filmu kinowego - przegląd literatury}

Funkcjonowanie produktu na rynku związane jest $\mathrm{z}$ pewnym okresem, w którym produkt przechodzi przez kilka stadiów sprzedaży. Zjawisko to nazywane jest „cyklem życia produktu” (Kotler, 2005). W 1965 roku Theodore Levitt zamieści w Harvard Business Review artykuł zaliczany dziś do klasyki teorii marketingu (Levitt, 1965). Autor przedstawił koncepcję cyklu życia produktu i omówił możliwości jej praktycznego zastosowania. Cykl ten obejmuje okres od momentu wejścia produktu na rynek do momentu wycofania $\mathrm{z}$ rynku. Składa się z czterech faz: wprowadzenie produktu na rynek (faza I), wzrost sprzedaży produktu (faza II), dojrzałość i nasycenie rynku produktem (faza III), spadek sprzedaży produktu (faza IV) (Kotler, 2005). Cały cykl przedstawiany został na schemacie ilustrującym wielkość sprzedaży jako funkcje czasu (rysunek 1). Tak rozumiany cykl życia produktu można opisać za pomocą równania:

$$
Y=a+b x+c x^{2} .
$$

Rysunek 1. Cykl życia produktu

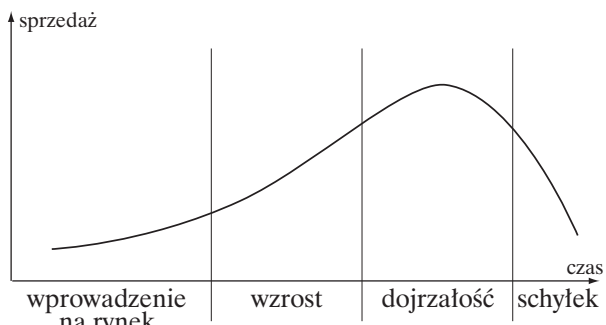

na rynek

Źródło: opracowanie własne na podstawie Kotler (2005).

Klasyczna koncepcja cyklu życia zakłada, że w okresie wprowadzenia produktu na rynek zysk jest ujemny, a sprzedaż rośnie powoli. W okresie wzrostu produkt jest szybko akceptowany przez rynek i następuje zdecydowana poprawa zysku (zysk staje się dodatni).

W okresie dojrzałości następuje spowolnienie wzrostu sprzedaży, zysk stabilizuje się (lub spada ze względu na rosnącą konkurencję), a produkt zostaje przyjęty przez większość potencjalnych nabywców. Ostatnim etapem w cyklu życia produktu jest faza schyłkowa, w którym następuje spadek sprzedaży i zysku.

W rzeczywistości cykl życia poszczególnych produktów odbiega najczęściej od przedstawionego klasycznego schematu.

Przegląd literatury wskazuje, iż na rynku filmów kinowych klasyczna koncepcja cyklu życia produktu nie znajduje zastosowania (Ainslie, Dreye i Zufryden, 2005; Castro i Rodriguez-Sickert, 2006; De VanyiWalls, 1996; Hidalgo, Sawhney i Eliashberg, 1996). Na podstawie wyników badań przeprowadzonych przez naukowców w Stanach Zjednoczonych można stwierdzić, iż dominujący wzorzec krzywej cyklu życia filmu kinowego przyjmuje kształt funkcji wykładniczej (Krider i Weinberg, 1998; Lehmann i Weinberg, 2000). Oznacza to, że kluczowe znaczenie ma pierwsza faza obecności filmu w kinie, czyli tydzień premierowy (Liu, 2006; Terry, De'Armond i Zachary, 2009; Hadida, 2009). Film, który nie osiąga dostatecznie dobrego „otwarcia”, a więc wysokich wyników sprzedażowych w pierwszym tygodniu, szybko zostaje wycofany z kin, ustępując miejsca innym bardziej atrakcyjnym produkcjom (Changi Ki, 2005; De Vany i Walls, 1997).

Dodatkowym wyzwaniem dla podmiotów wprowadzających nowy film na rynek jest krótki cykl życia w kanale kinowym, który wynosi od kilku do kilkunastu tygodni (Radas i Shugan, 1998). Oznacza to konieczność szybkiego pozyskania odpowiedniej liczby widzów w celu pokrycia poniesionych kosztów związanych z procesem produkcyjnym i komercjalizacją filmu kinowego (Basuroy, Desai i Talukdar, 2006).

\section{Problem i cele badawcze}

Specyfika kształtowania się krzywej cyklu życia filmu kinowego na rynku polskim nie została dotychczas empirycznie rozpoznana i potwierdzona. W celu zwiększenia prawdopodobieństwa sukcesu sprzedażowego nowego produktu filmowego, podmioty działające na rynku filmów kinowych w Polsce powinny poznać specyfikę kształtowania się cyklu życia produkcji kinowej. Główny problem badawczy niniejszego artykułu brzmi następująco: Jak kształtuje się krzywa cyklu życia filmu kinowego w Polsce?

Zdefiniowany problem badawczy stanowił podstawę do sformułowania szczegóło- 
wych pytań - celów badania, pozwalających w znacznym stopniu wyjaśnić charakter badań:

- Czy w grupie zróżnicowanych produktów, jakimi są filmy kinowe, można zaobserwować dominujący wzorzec kształtowania się trendu sprzedaży?

- Czy klasyczna koncepcja cyklu życia przybierająca kształt dzwonu i występowanie czterech podstawowych faz, tj. wprowadzenie, wzrost, dojrzałość i spadek sprzedaży znajduje zastosowanie na rynku filmów kinowych w Polsce?

\section{Próba badawcza}

Analizie poddano wstępnie 207 polskich filmów fabularnych. Próba ta stanowiła początkowo $97 \%$ populacji generalnej, jaką stanowity polskie filmy fabularne, które w analizowanym okresie obecne były w polskich kinach (źródło: baza danych „box office”). W ostatecznym modelowaniu panelowym uwzględniono jednak 175 produkcji kinowych (tzn. 82\% populacji generalnej) $\mathrm{z}$ uwagi na chęć zastosowania próby zbilansowanej 8 tygodni projekcji. Pominięte jednostki charakteryzowały się nietypowym czasem projekcji w kinach (zazwyczaj bardzo krótki okres) i wyjątkowo niewielką liczbą kopii. Były to produkcje na tyle niszowe, że można uznać je za nietypowe. Wszystkie filmy uwzględnione w badaniu charakteryzowały się zakończonym cyklem życia w kanale kinowym.

Zastosowany dobór próby badawczej określa się jako nielosową próbę badawczą. Jest to badanie w dużym stopniu wyczerpujące także $\mathrm{z}$ perspektywy analizowanego okresu, gdyż pomiarowi poddano stosunkowo długi okres od roku 2004 do roku 2014. Głównym celem była analiza możliwie jak największej liczby filmów kinowych, w przypadku których nie istniały bariery dostępu do niezbędnych informacji badawczych.

\section{Metodyka badań empirycznych}

Model regresji na próbie tzw. wymieszanej (panelowej) może być estymowany metodą najmniejszych kwadratów KMNK. Przy spełnieniu wszystkich założeń tej metody dostarcza ona efektywnych i zgodnych estymatorów wartości stałej $\alpha_{0}$ oraz wektora parametrów $\beta$. Postać modelu przedstawia się następująco (Greene, 2002):

$$
\begin{gathered}
y_{i t}=\mathrm{x}_{i t}^{\prime} \beta+\alpha_{0}+\varepsilon_{i t} \\
\text { dla } i=1,2, \ldots, \mathrm{N} \quad t=1,2, \ldots, \mathrm{T}
\end{gathered}
$$

gdzie:

$y_{i t}$ - wartość zmiennej endogenicznej w okresie ,t" dla obiektu ,i”

$\mathrm{x}_{i t}^{\prime}$ - wektor wartości k-zmiennych egzogenicznych w okresie „„" dla obiektu ,i”

$\beta$ - wektor złożony z k-parametrów przy zmiennych egzogenicznych

$\alpha_{0}$ - jednakowa dla wszystkich obiektów wartość stałej

$\varepsilon_{i t}$ - składnik resztowy w okresie „t” dla obiektu ,i”.

Powyższy model znajduje zastosowanie w badaniu syntetycznym (1). Zalety tego rodzaju analizy najłatwiej dostrzec w przypadku braku dostępu do dostatecznie długich szeregów czasowych. W tym przypadku liczba obserwacji w czasie jest zwielokrotniana przez obecność zbioru jednostek przekrojowych, dzięki czemu badacz dysponuje większą liczbą stopni swobody.

W badaniu można doszukać się również odwołania do modelu z efektami ustalonymi (fixed effects), który w zapisie dla wielu zmiennych objaśniających można przedstawić jako (Maddala, 2006):

$$
\begin{gathered}
y_{i t}=\alpha_{i}+\beta^{\prime} \mathrm{X}_{i t}+u_{i t} \\
\text { dla } i=1,2, \ldots, \mathrm{N} \quad t=1,2, \ldots, \mathrm{T}
\end{gathered}
$$

gdzie:

$\alpha_{i}=\mathrm{z}_{i}^{\prime} \alpha$ reprezentuje czynniki specyficzne dla danej jednostki przekrojowej, które swoim oddziaływaniem powodują różnice w wartościach średnich zmiennej endogenicznej.

Model powyższy (2) nazywany jest również zero-jedynkowym modelem najmniejszych kwadratów (east squares with dummyvariables - LSDV), ponieważ może zostać oszacowany na podstawie KMNK.

W praktyce często zachodzi potrzeba uwzględnienia w wiekszym zakresie specyfiki poszczególnych obiektów, stąd przyjmuje się, że współczynniki przy zmiennych objaśniających są różne dla różnych jednostek przekrojowych, ale stałe w czasie dla konkretnej jednostki (3). Model można zatem zapisać jako (Ciecieląg i Tomaszewski, 2003) $)^{1}$ : 


$$
\left[\begin{array}{c}
\mathrm{y}_{1} \\
\mathrm{y}_{2} \\
\vdots \\
\mathrm{y}_{N}
\end{array}\right]=\left[\begin{array}{cccc}
\mathrm{X}_{1} & 0 & \cdots & 0 \\
0 & \mathrm{X}_{2} & & \vdots \\
\vdots & & \ddots & 0 \\
0 & \cdots & 0 & \mathrm{X}_{N}
\end{array}\right] \times\left[\begin{array}{c}
\beta_{1} \\
\beta_{2} \\
\vdots \\
\beta_{N}
\end{array}\right]+\left[\begin{array}{c}
\varepsilon_{1} \\
\varepsilon_{2} \\
\vdots \\
\varepsilon_{N}
\end{array}\right]
$$

Oszacowanie modelu, który zawiera zróżnicowane współczynniki, często prowadzi do poprawy jego miary dopasowania $\mathrm{R}^{2}$. Jednak formułowane na podstawie badania wnioski stają się wówczas mniej uniwersalne.

\section{Badanie empiryczne zmienności w czasie wpływów na kopię z projekcji filmu kinowego w Polsce}

Badanie zostało rozpoczęte od próby stworzenia modelu w postaci możliwie najbardziej syntetycznej, czyli typowego modelu regresji na „próbie wymieszanej” (panelowego), która łączy dane o wymiarze czasowym i przekrojowym (tabela 1). Liniowy model opisujący zmienność całkowitych tygodniowych wpływów z projekcji danego filmu na kopię przedstawiono w tabeli 1.

Model liniowy charakteryzuje się niewielkim dopasowaniem do danych empi- rycznych według miary skorygowanego współczynnika determinacji (Adjusted R-squared 0.148748). Niskie dopasowanie modelu liniowego nie jest specjalnie zaskakujace, gdyż krzywa cyklu życia produktu rzadko przypomina funkcję liniową. Jednocześnie znamienne jest, że zarówno stała C, jak i zmienna obrazująca upływ czasu $\mathrm{T}$ są istotnie statystycznie różne od zera na podstawie testu t-Studenta (tabela 1).

Model wykładniczy wykazuje już znacznie wyższe dopasowanie do danych empirycznych niż model liniowy. Jednak nadal jest to dopasowanie niewielkie w okolicach 37,4\% (Adjusted R-squared $0.374085)$. Zatem tylko $37,4 \%$ zmienności logarytmu naturalnego wpływów na kopię $\mathrm{z}$ projekcji filmu kinowego zostało wyjaśnione upływem czasu w tygodniach od premiery. Funkcja wykładnicza jest najsilniej zbliżona kształtem do wykresu cyklu życia filmu kinowego jaki występuje w Polsce. W niniejszym badaniu testowano również inne funkcje nieliniowe, tzn. funkcję potęgową, hiperboliczną, logistyczną. W praktyce okazało się jednak, że najlepsze własności statystyczne i interpretacyjne prezentuje właśnie funkcja wykładnicza. W tym przypadku test t-Studenta również wskazuje na istotność statystyczną stałej

Tabela 1. Model liniowy zmienności w czasie wpływów na kopię z projekcji filmu kinowego w Polsce

Dependent Variable: WK?

Method: Pooled Least Squares

Number of cross-sections used: 175

Total panel (balanced) observations: 1400

\begin{tabular}{|l|c|l|c|c|}
\hline \multicolumn{1}{|c|}{ Variable } & Coefficient & \multicolumn{1}{c|}{ Std. Error } & t-Statistic & Prob. \\
\hline $\mathrm{C}$ & 15986.01 & 678.8321 & 23.54928 & 0.0000 \\
\hline $\mathrm{T}$ & -2106.127 & 134.4288 & -15.66723 & 0.0000 \\
\hline R-squared & 0.149357 & Mean dependent var & 6508.437 \\
\hline Adjusted R-squared & 0.148748 & \multicolumn{2}{|l|}{ S.D. dependent var } & 12491.28 \\
\hline S.E. of regression & 11524.87 & \multicolumn{2}{l|}{ Sum squared resid } & $1.86 \mathrm{E}+11$ \\
\hline F-statistic & 245.4622 & \multicolumn{2}{|l|}{ Durbin-Watson stat } & 2.127109 \\
\hline Prob(F-statistic) & 0.000000 & & & \\
\hline
\end{tabular}

gdzie:

WK - zmienna objaśniana, która określa całkowite tygodniowe wpływy na kopię z projekcji danego filmu kinowego;

$\mathrm{T}$ - zmienna objaśniająca, która ukazuje upływ czasu liczony w tygodniach od premiery danego filmu; C - wartość stała jednakowa dla wszystkich obiektów.

Źródło: opracowanie własne w programie Eviews 5. 
Dependent Variable: LOG(WK?)

Method: Pooled Least Squares

Number of cross-sections used: 175

Total panel (balanced) observations: 1400

\begin{tabular}{|l|c|c|c|c|}
\hline \multicolumn{1}{|c|}{ Variable } & Coefficient & \multicolumn{1}{c|}{ Std. Error } & t-Statistic & Prob. \\
\hline $\mathrm{C}$ & 9.662170 & 0.084576 & 114.2430 & 0.0000 \\
\hline $\mathrm{T}$ & -0.484585 & 0.016748 & -28.93314 & 0.0000 \\
\hline R-squared & 0.374532 & \multicolumn{2}{l|}{ Mean dependent var } & 7.481536 \\
\hline Adjusted R-squared & 0.374085 & S.D. dependent var & 1.814934 \\
\hline S.E. of regression & 1.435881 & \multicolumn{2}{l|}{ Sum squared resid } & 2882.334 \\
\hline F-statistic & 837.1264 & Durbin-Watson stat & 2.068293 \\
\hline Prob(F-statistic) & 0.000000 & & & \\
\hline
\end{tabular}

gdzie:

LOG(WK) - logarytm naturalny zmiennej objaśnianej, która określa całkowite tygodniowe wpływy na kopię z projekcji danego filmu kinowego.

Źródło: opracowanie własne w programie Eviews 5.

oraz zmiennej objaśniającej (tabela 2): Zapis modelu w postaci zlinearyzowanej został przedstawiony poniżej:

$$
\mathrm{LN}\left(\mathrm{WK}_{\mathrm{it}}\right)=-0,484585 \mathrm{~T}+9,662170
$$

Zatem w obrębie badanej próby można powiedzieć, że licząc od dnia premiery średnio z tygodnia na tydzień wpływy na kopię z projekcji filmu kinowego w Polsce maleją średnio o 48,5\% przy założeniu ceteris paribus. Postać pierwotna modelu dla funkcji wykładniczej przedstawia się następująco:

$$
\begin{aligned}
\mathrm{WK}_{\mathrm{it}} & =\mathrm{e}^{(-0,484585) \mathrm{T}} \mathrm{e}^{9,66217}= \\
& =0,615953^{\mathrm{T}} 15711,84
\end{aligned}
$$

Dla postaci niezlinearyzowanej modelu odczytać można średniookresową stopę spadku wpływów z projekcji filmu na kopię równą 38,4\% (5).

Oba przedstawione powyżej modele tzn. liniowy i wykładniczy (tabele 1 i 2 ) charakteryzują się wyjątkowo wysokimi wartościami testu t-Studenta dla stałej i zmiennej objaśniającej przy niewystarczającym dopasowaniu do danych empirycznych. Stąd zdecydowano się wprowadzić do modelu składnik $\alpha_{i}=\mathrm{z}_{i}^{\prime} \alpha$, który reprezentuje czynniki specyficzne (4) dla danej jednostki przekrojowej (tj. produkcji filmowej). W ten sposób otrzymano model z efektami ustalonymi, przedstawiony w tabeli $3^{2}$.

Jak widać, dodanie do modelu efektów ustalonych spowodowało znaczący wzrost dopasowania do danych empirycznych (Adjusted R-squared 0.918733). Tym razem prawie $92 \%$ zmienności logarytmu naturalnego wpływów na kopię z projekcji filmu kinowego zostało wyjaśnione upływem czasu w tygodniach od premiery (tabela 3 ). Zatem czas mierzony w tygodniach w połączeniu ze zróżnicowaną wartością stałą znakomicie objaśniają zmienność badanej zmiennej endogenicznej.

Testowanie istotności zróżnicowanych efektów indywidualnych w modelu z efektami ustalonymi przeprowadzono za pomocą testu F (Green, 2002) o następujących hipotezach:

$$
\begin{gathered}
\mathrm{H}_{0}: \alpha_{i t}=\alpha=\text { const } \\
\text { dla } \mathrm{i}=1, \ldots, \mathrm{N}, \quad \mathrm{t}=1, \ldots, \mathrm{T} \\
\mathrm{H}_{1}: \alpha_{i} \neq \alpha_{j} \text { oraz } \mathrm{H}_{0}: \alpha_{i t}=\alpha_{i s}=\alpha_{i} \\
\text { dla } \mathrm{i}=1, \ldots, \mathrm{N}, \quad \mathrm{t}, \mathrm{s}=1, \ldots, \mathrm{T}
\end{gathered}
$$

Wyniki obliczeń w programie Eviews wykazały konieczność odrzucenia hipotezy zerowej testu na korzyść hipotezy alter- 
Tabela 3. Model wykładniczy z efektami ustalonymi opisujący zmienność w czasie wpływów na kopię z projekcji filmu kinowego w Polsce

Dependent Variable: LOG(WK?)

Method: PooledLeastSquares

Cross-sectionsincluded: 175

Total pool (balanced) observations: 1400

\begin{tabular}{|c|c|c|c|c|}
\hline Variable & Coefficient & Std. Error & t-Statistic & Prob. \\
\hline T & -0.484585 & 0.006035 & -80.29664 & 0.0000 \\
\hline NMZ_--C & 6.513300 & 0.184929 & 35.22048 & 0.0000 \\
\hline OPK_-C & 8.612104 & 0.184929 & 46.56970 & 0.0000 \\
\hline PTA_--C & 13.45287 & 0.184929 & 72.74601 & 0.0000 \\
\hline SPR_--C & 9.914368 & 0.184929 & 53.61165 & 0.0000 \\
\hline EGO_--C & 10.34041 & 0.184929 & 55.91545 & 0.0000 \\
\hline SPA_-C & 10.90779 & 0.184929 & 58.98356 & 0.0000 \\
\hline SDL_--C & 10.91372 & 0.184929 & 59.01561 & 0.0000 \\
\hline SIN_--C & 9.994882 & 0.184929 & 54.04703 & 0.0000 \\
\hline TRI_-C & 9.930226 & 0.184929 & 53.69741 & 0.0000 \\
\hline WEN_--C & 9.604073 & 0.184929 & 51.93374 & 0.0000 \\
\hline R-squared & 0.928899 & \multicolumn{2}{|l}{ Mean dependent var } & 7.481536 \\
\hline Adjusted R-squared & 0.918733 & S.D. dependent var & 1.814934 \\
\hline S.E. of regression & 0.517388 & Akaike info criterion & 1.637035 \\
\hline Sum squaredresid & 327.6535 & Schwarz criterion & 2.296309 \\
\hline Log likelihood & -969.9244 & F-statistic & 91.37686 \\
\hline Durbin-Watson stat & 2.100766 & Prob(F-statistic) & 0.000000 \\
\hline
\end{tabular}

gdzie:

NMZ_--C, OPK_--C, PTA_--C itd. oznaczają wartości stałe oszacowane dla różnych produkcji filmowych zawartych w badāniu.

Źródło: opracowanie własne w programie Eviews 5.

natywnej przy poziomie istotności bliskim zero (6). Stąd całkowicie uzasadnione jest zastosowanie zróżnicowanych efektów indywidualnych (fixe effects) dla poszczególnych produkcji kinowych.

Zapis analityczny powstałego modelu zostanie podany $\mathrm{w}$ formie skróconej ze względu na wyjątkowo dużą liczbą jednostek przekrojowych w badaniu ${ }^{3}$.

$\mathrm{LN}\left(\mathrm{WK} \_\mathrm{NMZ}_{\mathrm{t}}\right)=-0,484585 \mathrm{~T}+6.513300$

$\mathrm{LN}\left(\mathrm{WK}_{-} \mathrm{OPC}_{\mathrm{t}}\right)=-0,484585 \mathrm{~T}+8.612104$

$\mathrm{LN}\left(\mathrm{WK} \mathrm{PTA}_{\mathrm{t}}\right)=-0,484585 \mathrm{~T}+13.45287$
$\mathrm{LN}\left(\mathrm{WK} \mathrm{SPR}_{\mathrm{t}}\right)=-0,484585 \mathrm{~T}+9.914368$

$\mathrm{LN}\left(\mathrm{WK} \_\mathrm{EGO}_{\mathrm{t}}\right)=-0,484585 \mathrm{~T}+10.34041$ :

LN $\left(\right.$ WK_SDL SD $\left._{t}\right)=-0,484585 \mathrm{~T}+10.91372$

$\mathrm{LN}\left(\mathrm{WK} \_S I N_{\mathrm{t}}\right)=-0,484585 \mathrm{~T}+9.994882$

$\mathrm{LN}\left(\mathrm{WK}\right.$ TRI $\left._{\mathrm{t}}\right)=-0,484585 \mathrm{~T}+9.930226$

$\mathrm{LN}\left(\mathrm{WK} \_\mathrm{WEN}_{\mathrm{t}}\right)=-0,484585 \mathrm{~T}+9.604073$

gdzie:

NMZ, OPK, PTA, ... itd. oznaczają nazwy kodowe poszczególnych produkcji filmowych ujętych w badaniu. 
Znaczny wzrost dopasowania modelu do danych empirycznych można uzyskać również stosując zróżnicowane oszacowania parametrów dla poszczególnych jednostek przekrojowych (3). Takie podejście do modelowania wydaje się interesujące, gdyż z uwagi na ubogi zbiór zmiennych objaśniających należy oczekiwać, że poza modelem występują czynniki mające wpływ na zmienną endogeniczną. W tej sytuacji Jeśli kowariancje pomiędzy różnymi jednostkami są niezerowe $E\left(\varepsilon_{i} \varepsilon_{j} \neq 0\right.$ to estymator uogólnionej metody najmniejszych kwadratów wektora parametrów $\beta$ jest bardziej efektywny niż oszacowania uzyskane na podstawie pojedynczych równań (Maddala, 2006). Literatura podpowiada, że do oszacowania parametrów modelu można wykorzystać wówczas metodę szacowania pozornie niezależnych regresji (seemingly- unrelatedregression - SUR) zaproponowaną przez Zellnera (1962).

Model zawierający zróżnicowane oszacowania parametrów dla poszczególnych jednostek (tabela 4) cechuje się również wysoką wartością skorygowanego współczynnika determinacji, choć jest to wartość mniejsza o prawie $5 \% \mathrm{w}$ porównaniu do modelu z efektami ustalonymi (tabela 3 ).

Zapis formy zlinearyzowanej modelu ze zróżnicowanymi parametrami zostanie podany $\mathrm{w}$ formie skróconej ze względu na dużą liczbą jednostek przekrojowych w badaniu.

$\mathrm{LN}\left(\mathrm{WK} \mathrm{NMZ}_{\mathrm{t}}\right)=-1.066650 \mathrm{~T}+9.662170$

$\mathrm{LN}\left(\mathrm{WK}^{-} \mathrm{OPC}_{\mathrm{t}}\right)=-0.658287 \mathrm{~T}+9.662170$

$\mathrm{LN}\left(\mathrm{WK}^{-} \mathrm{PTA}_{\mathrm{t}}\right)=-0.251875 \mathrm{~T}+9.662170$

$\mathrm{LN}\left(\mathrm{WK} \mathrm{SPR}_{\mathrm{t}}\right)=-0.392343 \mathrm{~T}+9.662170$

$\mathrm{LN}\left(\mathrm{WK}_{-} \mathrm{EGO}_{\mathrm{t}}\right)=-0.332016 \mathrm{~T}+9.662170$

Tabela 4. Model wykładniczy ze zróżnicowanymi parametrami ${ }^{4}$

Dependent Variable: LOG(WK?)

Cross-sectionsincluded: 175

Total pool (balanced) observations: 1400

\begin{tabular}{|c|c|c|c|c|}
\hline Variable & Coefficient & Std. Error & t-Statistic & Prob. \\
\hline C & 9.662170 & 0.038342 & 251.9986 & 0.0000 \\
\hline NMZ_-T & -1.066650 & 0.046075 & -23.15010 & 0.0000 \\
\hline OPK_-T & -0.658287 & 0.046075 & -14.28715 & 0.0000 \\
\hline PTA_-T & -0.251875 & 0.046075 & -5.466585 & 0.0000 \\
\hline SPR_-T & -0.392343 & 0.046075 & -8.515236 & 0.0000 \\
\hline EGO_-T & -0.332016 & 0.046075 & -7.205921 & 0.0000 \\
\hline$\vdots$ & & & & \\
\hline SDL_-T & -0.233039 & 0.046075 & -5.057784 & 0.0000 \\
\hline SIN_-T & -0.437626 & 0.046075 & -9.498044 & 0.0000 \\
\hline TRI_-T & -0.469351 & 0.046075 & -10.18657 & 0.0000 \\
\hline WEN_-T & -0.463329 & 0.046075 & -10.05588 & 0.0000 \\
\hline R-squared & 0.887451 & \multicolumn{2}{|l}{ Mean dependent var } & 7.481536 \\
\hline Adjusted R-squared & 0.871359 & S.D. dependent var & 1.814934 \\
\hline S.E. of regression & 0.650954 & Akaike info criterion & 2.096325 \\
\hline Sum squaredresid & 518.6589 & Schwarz criterion & 2.755599 \\
\hline Log likelihood & -1291.427 & F-statistic & 55.14993 \\
\hline Durbin-Watson stat & 2.040576 & Prob(F-statistic) & 0.000000 \\
\hline
\end{tabular}

Źródło: opracowanie własne w programie Eviews 5. 
$\mathrm{LN}\left(\mathrm{WK} \quad \mathrm{SDL}_{\mathrm{t}}\right)=-0.233039 \mathrm{~T}+9.662170$

$\mathrm{LN}\left(\mathrm{WK} \mathrm{SIN}_{\mathrm{t}}\right)=-0.437626 \mathrm{~T}+9.662170$

$\mathrm{LN}\left(\mathrm{WK}_{-}^{-} \mathrm{TRI}_{\mathrm{t}}\right)=-0.469351 \mathrm{~T}+9.662170$

$\mathrm{LN}\left(\mathrm{WK}_{-} \mathrm{WEN}_{\mathrm{t}}\right)=-0.463329 \mathrm{~T}+9.662170$

\section{Podsumowanie}

Odwołanie do modelu ze zróżnicowanymi parametrami miało na celu zwrócenie uwagi czytelnika na zgodność znaków oszacowań oraz relatywnie niewielkie różnice w wartościach parametrów dla większości jednostek przekrojowych próby (tabela 4). Celem zasadniczym opracowania jest chęć ukazania zastosowania modelowania opartego na próbie panelowej do wyznaczenia krzywej cyklu życia filmu kinowego w Polsce. Wydaje się, że zasadnicze znaczenie posiada tutaj estymacja parametru, który w syntetyczny sposób opisze zmienność wpływów na kopię w czasie. Odpowiedzi należy zatem szukać raczej w modelach typu fixe effects (tabela 3) lub nawet w modelach pozbawionych tego efektu (tabela 2). Przeprowadzone badania empiryczne sugerują, że jest to możliwe pomimo ogromnej zmienności produktu, jakim jest film kinowy w Polsce. Wstępne modele wykazały kluczowe znaczenie zmiennej obrazującej upływ czasu w tygodniach, choć początkowo dopasowanie do danych empirycznych było niewystarczające. Okazuje się, że kryterium dopasowania modelu nie odgrywa tutaj roli najważniejszej. W przypadku zróżnicowanego produktu filmowego pojawiają się różne dla różnych jednostek przekrojowych przesunięcia krzy- wej cyklu życia względem osi rzędnych na co wskazuje model $\mathrm{z}$ efektami ustalonymi (tabela 3). Model z efektami ustalonymi zawarty w artykule ma za zadanie zobrazowanie wzrostu dopasowania modelu do danych empirycznych pod wpływem wprowadzenia różnych oszacowań stałej. Jednak sam parametr zawarty w zlinearyzowanej funkcji wykładniczej pozostaje taki sam (tj. -0.484585 , tabele 2 i 3). Parametr ten wyraża przebieg uśrednionej dla wszystkich jednostek krzywej cyklu życia produktu filmowego.

Zastosowanie metodyki modelowania opartego na próbie panelowej pomaga w przypadku produktów filmowych dokonać pewnych uśrednień, które nie byłyby możliwe na podstawie modeli pojedynczej regresji. Ponadto pojawiłby się w tym wypadku problem niewystarczajacej liczby danych w próbie, który pomagają rozwiązać modele łaczace wymiar czasowy z przekrojowym obserwowanego zjawiska. Można sobie wyobrazić, że idac dalszym tropem wprowadzania do modelu efektów specyficznych dla poszczególnych jednostek przekrojowych należałoby uwzględnić jednocześnie zróżnicowaną stałą (fixe effects) (2) oraz zróżnicowane parametry (3). Model tego typu również został zbudowany i odznacza się wyjątkowo wysokim dopasowaniem do danych empirycznych (Adjusted R-squared 0.973099), jednak jego własności nie pozwalają na dokonywanie uogólnień (tj. uśrednień opisujących wspólną krzywą cyklu życia produktu filmowego), ze względu na zbyt złożoną strukturę modelu.

Analizując kształt krzywej cyklu życia filmu kinowego można jednoznacznie

Rysunek 2. Krzywa cyklu życia produktu filmowego na podstawie modelu opartego na próbie panelowej

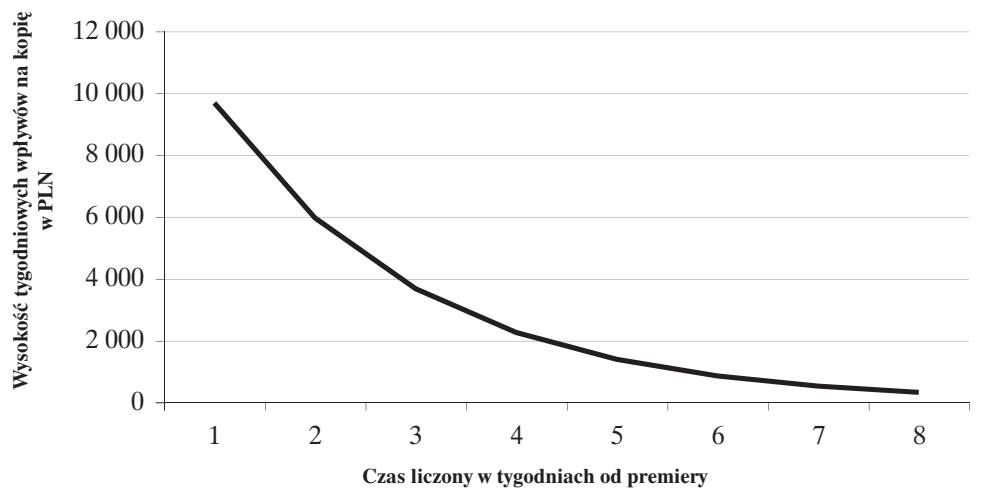

Źródło: opracowanie własne w programie Eviews 5. 
stwierdzić, że klasyczna koncepcja cyklu życia produktu przybierająca kształt dzwonu i występowanie czterech sekwencyjnych faz sprzedaży nie znajduje zastosowania na rynku filmów kinowych w Polsce. Na podstawie wyników badania można stwierdzić, iż krzywa cyku życia filmu kinowego w Polsce przyjmuje kształt funkcji wykładniczej. Najwyższą sprzedaż produkt filmowy generuje w pierwszym tygodniu projekcji kinowej. W kolejnych tygodniach następuje regularny spadek sprzedaży biletów kinowych.

\section{Przypisy}

1 W obliczeniach wykorzystano program ekonometryczny Eviews 5.

2 Z uwagi na przejrzystość opracowania w tabel pominięto oszacowania stałej dla wielu jednostek próby, gdyż oszacowania te zajmowały pierwotnie kilka stron tekstu.

3 Przedstawiona forma modelu została ograniczona do przykładowych jednostek, gdyż w całości zapis zawierał stosunkowo dużą liczbę równań.

$4 \quad$ Z uwagi na przejrzystość opracowania w tabeli pominięto oszacowania parametrów dla wielu jednostek próby, gdyż estymatory te zajmowałyby kilka stron tekstu.

\section{Bibliografia}

Ainslie, A., Dreye, X. i Zufryden, F. (2005). Modeling movie life cycles and market share. Marketing Science, 24(3), 508-517, http://dx.doi.org/10.1287/ mksc.1040.0106.

Basuroy, S., Desai, K. i Talukdar, D. (2006). An empirical investigation of signaling in the motion picture industry. Journal of Marketing Research, 43(2), 287-295, http://dx.doi.org/10.1509/ jmkr.43.2.287.

Chang, B.H. i Ki, E.J. (2005). Devising a practical model for predicting theatrical movie success: focusing on the experience good property. Journal of Media Economics, 18(4), 247-269, http://dx.doi. org/10.1207/s15327736me1804_2.

Ciecieląg, J. i Tomaszewski, A. (2003). Ekonometryczna analiza danych panelowych. Warszawa: Wydawnictwo WNE.

Dańska-Borsiak, B. i Laskowska, I. (2006). Wybrane problemy estymacji modeli opartych na danych czasowo-przekrojowych. Przeglad Statystyczny, 53(3), 27-35.

De Vany, A.S. i Walls, W.D. (1996). Bose-Einstein dynamics and adaptive contracting in the motion picture industry. The Economic Journal, 106(439), 1493-1514, http://dx.doi.org/10.2307 12235197 .
De Vany, A.S. i Walls, W.D. (1997). The market for motion pictures: rank, revenue, and survival. Economic Inquiry, 35(4), s.783-798, http://dx.doi. org/10.1111/j.1465-7295.1997.tb01964.x.

Green, W.H. (2002). Econometric analysis. New Jersey: Prentice Hall.

Hadida, A.L. (2009). Motion picture performance: a review and research agenda. International Journal of Management Review, 11(3), 3010-304, http:// dx.doi.org/10.1111/j.1468-2370.2008.00240.x.

Hidalgo, C.A.R., Castro, A. i Rodriguez-Sickert, C. (2006). The effect of social interactions in the primary consumption life cycle of motion pictures. New Physics, 8(52), 1-11.

Kotler, Ph. (2005). Marketing. Poznań: Dom Wydawniczy Rebis.

Krider, R.E. i Weinberg, Ch. B. (1998). Competitive dynamics and the introduction of new products: the motion picture timing game. Journal of Marketing Research, 35(1), 1-15, http://dx.doi. org/10.2307/3151926.

Lehmann, D.R. i Weinberg, Ch.B. (2000). Sale through sequential distribution channels: an application to movies and videos. Journal of Marketing, 64(3), 18-34, http://dx.doi.org/10.1509/jmkg.64.3.18.18026.

Levitt, T. (1965). Exploit the product life cycle. Harvard Business Review, 43(3), 81-94.

Liu, Y. (2006). Word of mouth for movies: its dynamics and impact on box office revenue. Journal of Marketing, 70(3), 74-89, http://dx.doi.org/10.1509/ jmkg.70.3.74.

Maddala, G.S. (2006). Ekonometria. Warszawa: Wydawnictwo Naukowe PWN.

Radas, S. i Shugan, S.M. (1998). Seasonal marketing and timing new product introductions. Journal of Marketing Research, 35(3), 296-315, http://dx.doi. org/10.2307/3152029.

Reinstein, D.A. i Snyder, Ch.M. (2005). The influence of expert reviews on consumer demand for experience goods: a case study of movie critics. Journal of Industrial Economics, 53(1), 27-51, http://dx.doi.org/10.1111/j.0022-1821.2005.00244.

Sawhney, M.S. i Eliashberg, J. (1996). A parsimonious model of forecasting gross box-office revenues of motion pictures, Marketing Science, 15(2), 113-131, http://dx.doi.org/10.1287 /mksc.15.2.113.

Terry, N., De'Armond, D. i Zachary, M. (2009). The determinants of opening weekend box office revenue for movies. Journal of Academy of Business and Economics, 9(4), 193-201.

Zellner, A. (1962). An efficient method of estimating seemingly unrelated regressions and tests of aggregation bias. Journal of the American Statistical Assosiation, 57(198), 348-368, http://dx.doi.org/10. 1080/01621459.1962.10480664. 